University of Nebraska - Lincoln

DigitalCommons@University of Nebraska - Lincoln

USDA Forest Service / UNL Faculty Publications U.S. Department of Agriculture: Forest Service -National Agroforestry Center

2013

Carbon storage and sequestration by trees in urban and community areas of the United States

\author{
David J. Nowak \\ USDA Forest Service, dnowak@fs.fed.us \\ Eric J. Greenfield \\ USDA Forest Service, ejgreenfield@fs.fed.us \\ Robert E. Hoehn \\ USDA Forest Service, rhoehn@fs.fed.us \\ Elizabeth Lapoint \\ USDA Forest Service, elapoint@fs.fed.us
}

Follow this and additional works at: https://digitalcommons.unl.edu/usdafsfacpub

Nowak, David J.; Greenfield, Eric J.; Hoehn, Robert E.; and Lapoint, Elizabeth, "Carbon storage and sequestration by trees in urban and community areas of the United States" (2013). USDA Forest Service / UNL Faculty Publications. 238.

https://digitalcommons.unl.edu/usdafsfacpub/238

This Article is brought to you for free and open access by the U.S. Department of Agriculture: Forest Service -National Agroforestry Center at DigitalCommons@University of Nebraska - Lincoln. It has been accepted for inclusion in USDA Forest Service / UNL Faculty Publications by an authorized administrator of DigitalCommons@University of Nebraska - Lincoln. 


\title{
Carbon storage and sequestration by trees in urban and community areas of the United States
}

\author{
David J. Nowak $^{\mathrm{a}, *}$, Eric J. Greenfield ${ }^{\mathrm{a}}$, Robert E. Hoehn ${ }^{\mathrm{a}}$, Elizabeth Lapoint ${ }^{\mathrm{b}}$ \\ ${ }^{a}$ USDA Forest Service, Northern Research Station, Syracuse, NY 13210, USA \\ ${ }^{\mathrm{b}}$ USDA Forest Service, Northern Research Station, Durham, NH 03824, USA
}

\section{A R T I C L E I N F O}

\section{Article history:}

Received 17 December 2012

Received in revised form

10 March 2013

Accepted 12 March 2013

\section{Keywords:}

Ecosystem services

Global climate change

Urban forestry

Tree cover

Forest inventory

\begin{abstract}
A B S T R A C T
Carbon storage and sequestration by urban trees in the United States was quantified to assess the magnitude and role of urban forests in relation to climate change. Urban tree field data from 28 cities and 6 states were used to determine the average carbon density per unit of tree cover. These data were applied to statewide urban tree cover measurements to determine total urban forest carbon storage and annual sequestration by state and nationally. Urban whole tree carbon storage densities average $7.69 \mathrm{~kg} \mathrm{C} \mathrm{m}{ }^{-2}$ of tree cover and sequestration densities average $0.28 \mathrm{~kg} \mathrm{C} \mathrm{m}^{-2}$ of tree cover per year. Total tree carbon storage in U.S. urban areas (c. 2005) is estimated at 643 million tonnes ( $\$ 50.5$ billion value; $95 \% \mathrm{CI}=597$ million and 690 million tonnes) and annual sequestration is estimated at 25.6 million tonnes ( $\$ 2.0$ billion value; $95 \% \mathrm{CI}=23.7$ million to 27.4 million tonnes).
\end{abstract}

Published by Elsevier Ltd.

\section{Introduction}

Urban trees and forests affect climate change, but are often disregarded because their ecosystem services are not wellunderstood or quantified. Trees act as a sink for carbon dioxide $\left(\mathrm{CO}_{2}\right)$ by fixing carbon during photosynthesis and storing carbon as biomass. The net long-term $\mathrm{CO}_{2}$ source/sink dynamics of forests change through time as trees grow, die, and decay. Human influences on forests (e.g., management) can further affect $\mathrm{CO}_{2}$ source/sink dynamics of forests through such factors as fossil fuel emissions and harvesting/utilization of biomass (Nowak et al., 2002). Trees in urban areas (i.e., urban forests) currently store carbon, which can be emitted back to the atmosphere after tree death, and sequester carbon as they grow. Urban trees also influence air temperatures and building energy use, and consequently alter carbon emissions from numerous urban sources (e.g., power plants) (Nowak, 1993). Thus, urban trees influence local climate, carbon cycles, energy use and climate change (e.g., Abdollahi et al., 2000; Wilby and Perry, 2006; Gill et al., 2007; Nowak, 2010; Lal and Augustine, 2012).

Urban areas in the conterminous United States have increased from $2.5 \%$ of the U.S. land area (19.5 million ha) in 1990 to $3.1 \%$

\footnotetext{
* Corresponding author.

E-mail addresses: dnowak@fs.fed.us (D.J. Nowak), ejgreenfield@fs.fed.us (E.J. Greenfield), rhoehn@fs.fed.us (R.E. Hoehn), elapoint@fs.fed.us (E. Lapoint).
}

(24.0 million ha) in 2000, an increase in area the size of Vermont and New Hampshire combined (Nowak et al., 2005). If the growth patterns of the 1990s continue, urban land is projected to reach $8.1 \%$ by 2050 , an increase greater than the area of Montana (Nowak and Walton, 2005). Within these urban areas, tree cover (circa 2005 ) is estimated at 35.0\% (Nowak and Greenfield, 2012b).

Given the growing expanse of urban areas, trees within these areas have the potential to store and annually sequester substantial amounts of carbon. Understanding this national carbon effect can aid in preparing annual inventories of greenhouse gas (GHG) emissions and sinks (U.S. EPA, 2010; Heath et al., 2011). Numerous cities in the United States have analyzed carbon storage and sequestration of the trees and forests among various land-use types using the i-Tree methodology (www.itreetools.org) (Table 1) or other methods (Hutyra et al., 2011; Raciti et al., 2012). In addition, cities outside the United States have also analyzed carbon storage by urban vegetation (e.g., Brack, 2002; Jo, 2002; Chaparro and Terradas, 2009; Zhao et al., 2010; Davies et al., 2011; Strohbach and Haase, 2012).

In the past, city analyses of carbon storage and sequestration have been extrapolated to national estimates using limited data. The first estimate of national carbon storage by urban trees (between 350 and 750 million tonnes; Nowak, 1993) was based on an extrapolation of carbon data from one city (Oakland, CA) and tree cover data from various U.S. cities (e.g., Nowak et al., 1996). A later assessment, which included data from a second city (Chicago, IL), estimated national carbon storage by urban trees between 600 and 
Table 1

City and state data used for carbon estimates. Plot size $=0.04$ ha unless noted otherwise.

\begin{tabular}{|c|c|c|c|c|}
\hline City/State & Year & No. plots & Data collection group & Reference \\
\hline Arlington, $\mathrm{TX}^{\mathrm{a}}$ & 2009 & 233 & City of Arlington & \\
\hline Atlanta, $\mathrm{GA}^{\mathrm{a}}$ & 1997 & 205 & ACRT, Inc. & \\
\hline Baltimore, $\mathrm{MD}^{\mathrm{a}}$ & 2009 & 195 & US Forest Service (USFS) & \\
\hline Boston, MA & 1996 & 217 & ACRT, Inc. & \\
\hline Casper, WY & 2006 & 234 & City of Casper & Nowak et al., 2006c \\
\hline Chicago, IL & 2007 & 745 & City of Chicago, Chicago Park District, USFS & Nowak et al., 2010b \\
\hline Freehold, $\mathrm{NJ}^{\mathrm{a}}$ & 1998 & 144 & NJ Dept. Env. Protection & \\
\hline Gainesville, FL & 2007 & 93 & Univ. Florida, USFS & Escobedo et al., 2009 \\
\hline Golden, $\mathrm{CO}^{\mathrm{a}}$ & 2007 & 115 & Inst. of Environmental Solutions & \\
\hline Hartford, $\mathrm{CT}^{\mathrm{a}}$ & 2007 & 200 & Knox Parks Foundation & \\
\hline Jersey City, $\mathrm{NJ}^{\mathrm{a}}$ & 1998 & 220 & NJ Dept. Env. Protection & \\
\hline Lincoln, NE & $2008 / 09$ & 178 & Nebraska Forest Service & \\
\hline Los Angeles, CA & $2007 / 08$ & 348 & USFS, Univ. Cal., Riverside & Nowak et al., 2011 \\
\hline Milwaukee, $\mathrm{WI}^{\mathrm{a}}$ & 2008 & 216 & City of Milwaukee & \\
\hline Minneapolis, MN & 2004 & 110 & Davey Resource Group & Nowak et al., 2006a \\
\hline Moorestown, $\mathrm{NJ}^{\mathrm{a}}$ & 2000 & 206 & NJ Dept. Env. Protection & \\
\hline Morgantown, WV & 2004 & 136 & West Virginia University & Nowak et al., 2012c \\
\hline New York, NY & 1996 & 206 & ACRT, Inc. & Nowak et al., 2007d \\
\hline Oakland, $\mathrm{CA}^{\mathrm{b}}$ & 1989 & 1350 & USFS & Nowak, 1991 \\
\hline Omaha, NE & $2008 / 09$ & 189 & Nebraska Forest Service & \\
\hline Philadelphia, PA & 1996 & 210 & ACRT, Inc. & Nowak et al., 2007b \\
\hline Roanoke, $\mathrm{VA}^{\mathrm{a}}$ & 2010 & 160 & Virginia Tech & \\
\hline Sacramento, $\mathrm{CA}^{\mathrm{a}}$ & 2007 & 300 & Sacramento Tree Foundation & \\
\hline San Francisco, CA & 2004 & 194 & San Francisco Dept. of the Environment & Nowak et al., 2007c \\
\hline Scranton, PA & 2006 & 182 & $\begin{array}{l}\text { Northeast PA Urban Forestry Program, Keystone College, } \\
\text { Penn State Extension, PA Dept. of Conservation } \\
\text { and Natural Resources }\end{array}$ & Nowak et al., 2010a \\
\hline Syracuse, NYa & 2009 & 198 & USFS & \\
\hline Washington, DC & 2004 & 201 & Casey Trees, University of Maryland, National Park Service & Nowak et al., 2006b \\
\hline Woodbridge, $\mathrm{NJ}^{\mathrm{a}}$ & 2000 & 215 & NJ Department of Environmental Protection & \\
\hline Indiana $\mathrm{c}^{\mathrm{s}}$ & 2002 & 32 & State Forestry personnel, USFS & Nowak et al., 2007a \\
\hline Kansas $^{c}$ & $2008 / 09$ & 188 & State Forestry personnel & Nowak et al., 2012b \\
\hline Nebraska ${ }^{c}$ & $2008 / 09$ & 200 & State Forestry personnel & Nowak et al., 2012b \\
\hline North Dakota ${ }^{c}$ & $2008 / 09$ & 299 & State Forestry personnel & Nowak et al., 2012b \\
\hline South Dakota ${ }^{\mathrm{c}}$ & $2008 / 09$ & 200 & State Forestry personnel & Nowak et al., 2012b \\
\hline Tennessee $^{c}$ & 2005-09 & 255 & State Forestry personnel, USFS & Nowak et al., 2012a \\
\hline
\end{tabular}

\footnotetext{
a Unpublished data.

b Variable plot size.

c 0.067 ha plot size.
}

900 million tonnes (Nowak, 1994). The most recent analysis, which used data from 10 cities and urban tree cover estimates (Nowak et al., 2001) derived from 1991 Advanced Very High Resolution Radiometer (AVHRR) data, estimated national carbon storage by urban forests at 700 million tonnes (range: 335 million-980 million tonnes) (Nowak and Crane, 2002). Above and below ground biomass in all forestland across the United States, which includes forest stands within urban areas, stored approximately 20.2 billion tonnes of carbon in 2008 (Heath et al., 2011).

The purpose of this paper is to update the national urban tree carbon storage and sequestration estimates using urban field data from 28 cities and 6 states and newer estimates of urban land area and urban tree cover. This new assessment produces more refined statistical estimates of the uncertainty of the national estimates and investigates the overlap between urban forest carbon estimates and U.S. forestland carbon estimates. These carbon storage and sequestration estimates provide better, more up-to-date information for national carbon estimates (e.g., IPCC, 2006) and can be used to help assess the actual and potential role of urban forests in reducing atmospheric $\mathrm{CO}_{2}$.

\section{Materials and methods}

The methods of this study used: (a) field data and model analyses from several cities and states to estimate total carbon storage and sequestration in these areas, (b) photo-interpretation of tree cover in these areas to determine carbon densities per unit of tree cover, and (c) photo-interpretation of tree cover in urban and community areas in each U.S. state to estimate statewide urban forest carbon values. As forest values from the national Forest Inventory and Analysis (FIA) program (hereby referred to as "forestland") overlap with urban estimates (because there are forest stands within urban areas), analysis of forestland plots within urban areas was conducted to determine the overlap between national forestland carbon estimates and national urban forest carbon estimates.

The definition of urban is based on population density using the U.S. Census Bureau's (2007) definition: all territory, population, and housing units located within urbanized areas or urban clusters. The definition of community, which includes cities, is based on jurisdictional or political boundaries delimited by U.S. Census Bureau definitions of incorporated or designated places (U.S. Census Bureau, 2007). Community areas may include all, some, or no urban land within their boundaries, but city areas are often dominated by urban land. As urban land encompasses the more heavily populated areas (population density-based definition) and community land has varying amounts of urban land that are recognized by their geopolitical boundaries (political definition), the category of "urban/community" was created to classify the union of these two geographically overlapping definitions where most people live. Urban land in 2000 occupied $3.1 \%$ (24.0 million ha) of the conterminous United States (Nowak et al., 2005), while urban/community land occupied 5.3\% (40.4 million ha) (Nowak and Greenfield, 2012b).

Forestlands at the national scale, as defined by the U.S. Department of Agriculture (USDA) Forest Service Forest Inventory and Analysis (FIA) program, are areas at least 0.4 ha ( $1 \mathrm{ac}$ ) in size, at least $36.6 \mathrm{~m}$ (120 feet) wide, and at least $10 \%$ stocked. To be measured as "forestland", plots must also not be affected by a land use that prevents normal tree regeneration and succession such as mowing, intensive grazing, or recreational activities (USDA Forest Service, 2010). Forestlands are estimated to cover 304 million ha in the United States (Smith et al., 2009). These forestlands include some areas that fall within urban and community areas.

\subsection{Field data}

Field data were used to determine the entire urban forest structure (e.g., tree species composition and number of trees on all land uses) for 28 U.S. cities and urban areas in 6 states (Table 1). These cities were sampled based on methods developed by the USDA Forest Service for various urban forest research projects (e.g., Nowak 
et al., 2008) and national urban forest monitoring (Cumming et al., 2008). Data collection was based on random sampling of 0.04 ha $(1 / 10 \mathrm{ac}$ ) plots (in cities) or 0.067 ha (four $1 / 24$ ac sub-plots) plots (in urban areas of states) and analyzed using the i-Tree Eco (formerly Urban Forest Effects (UFORE)) model (Nowak et al., 2008). The state plots were based on FIA plot design and data were collected as part of pilot projects testing FIA data collection in urban areas (Cumming et al., 2008). The number of plots collected varied by location (Table 1 ) with data collection including tree species, stem diameter at $1.37 \mathrm{~m}$ above the ground (DBH), tree and crown height, crown width, crown light exposure, and canopy condition. For each tree sampled, carbon storage and annual sequestration were estimated using biomass and growth equations. To aid in national estimates of carbon storage and sequestration, the carbon data are standardized per unit of tree cover.

\subsection{Biomass equations}

Biomass for each measured tree (minimum tree size $=2.54 \mathrm{~cm}$ dbh) was calculated using allometric equations and conversion factors from the literature to estimate whole tree dry weight biomass and carbon (see Nowak, 1994; Nowak et al., 2008). These equations are based on forest-grown trees, but as open-grown, maintained trees tend to have less above-ground biomass than predicted by forest-derived biomass equations for trees of the same $\mathrm{DBH}$, biomass results for open-grown urban trees were multiplied by a factor 0.8 (Nowak, 1994). No adjustment was made for trees found in more natural stand conditions (e.g., on vacant lands or in forest preserves). If no allometric equation could be found for an individual species, the average of results from equations of the same genus was used. If no genus equations were found, the average of results from all broadleaf or conifer equations was used.

The carbon estimates yield a standard error of the estimate based on sampling error, rather than error of estimation. Estimation error is unknown and likely large than the reported sampling error. Estimation error includes the uncertainty of using biomass equations and conversion factors, which may be large, as well as measurement error, which is typically small.

To estimate monetary value associated with urban tree carbon storage and sequestration, carbon values are multiplied by $\$ 78.5$ per tonne of carbon (range $=\$ 17.2-128.7 \mathrm{tC}^{-1}$ ) based on the estimated social costs of carbon for 2010 with a $3 \%$ discount rate (Interagency Working Group, 2010).

\subsection{Urban Tree growth and carbon sequestration}

Measured tree growth rates for street (Frelich, 1992; Fleming, 1988; Nowak 1994), park (deVries, 1987), and forest (Smith and Shifley, 1984) trees were standardized to length of growing season and adjusted for site competition and tree condition. The measured tree growth rates were standardized to 153 frost free days based on: Standardized growth $(\mathrm{SG})=$ measured growth rate $\times(153 \div$ number of frost free days of measurement) (Nowak et al., 2008). The 153 days was used as the reference length as this was the minimum length of the growing season from the measured data.

Standardized growth rates of trees of the same species or genera were then compared to determine the average difference between standardized street tree growth and standardized park and forest growth rates. Park growth averaged 1.78 times less than street tree growth, and forest growth averaged 2.29 times less than street tree growth. Crown light exposure (CLE) measurements (number of sides and/ or top of tree exposed to sunlight) of $0-1$ were used to represent forest growth conditions; $2-3$ for park conditions; and $4-5$ for open-grown (street tree) conditions. Local tree base growth rate (BG) was then calculated as the average standardized growth rate for open-grown trees $\left(0.83 \mathrm{~cm}\right.$ year $\left.{ }^{-1}\right) \times$ number of frost free days $\div 153$. CLE adjusted growth rate was: $\mathrm{BG} \div 2.26$ for CLE $0-1 ; \mathrm{BG} \div 1.78$ for $\mathrm{CLE}$ 2-3: and BG $\div 1$ for CLE 4-5 (Nowak et al., 2008)

The CLE adjusted growth rate was then adjusted based on tree condition to determine the final growth rate. For trees in fair to excellent condition, base growth rates are multiplied by 1 (no adjustment), for trees in poor condition (26-50\% dieback) growth rates are multiplied by 0.62 , critical trees ( $51-75 \%$ dieback) by 0.37 , dying trees (76-99\% dieback) by 0.13 and dead trees (100\% dieback) by 0 (Nowak et al., 2008). Adjustment factors are based on percent crown dieback and the assumption that less than $25 \%$ crown dieback has a limited effect on growth rates The difference in estimates of carbon storage between year $x$ and year $(x+1)$ is the gross amount of carbon sequestered annually.

Tree death leads to the eventual release of stored carbon. To estimate the net amount of carbon sequestered by the urban trees, carbon emissions due to decomposition of dead trees were calculated based on methods detailed in Nowak and Crane (2002). To estimate the net carbon sequestration rate, the amount of carbon sequestered due to tree growth was reduced by the estimated amount of carbon lost due to tree mortality and decay.

\subsection{Tree cover estimates}

Tree cover within each sample city was assessed using either photointerpretation or ground plot measurements of tree cover. Tree cover in urban areas and "urban/community" areas in each state was assessed using photointerpretation of aerial images circa 2005 (Nowak and Greenfield, 2012b).

\subsection{State and national level estimates}

Carbon and tree cover data for individual cities and states were used to calculate the total carbon storage and sequestration values standardized to per unit tree cover $\left(\mathrm{kg} \mathrm{C} \mathrm{m}{ }^{-2}\right.$; Table 2$)$. The carbon storage standardized values were pooled to determine a national average standardized value and associated standard error. The average standardized value was multiplied by tree cover and associated standard error in urban and urban/community areas in each state (Nowak and Greenfield, $2012 b)$ to estimate state and national totals for carbon storage. As tree growth and thus carbon sequestration can vary by length of growing season, the standardized sequestration values for each sampled city/state were divided by its length of growing season (number of days) to determine the average sequestration per day per unit of tree cover. This average value was multiplied by the average length of growing season and tree cover for each state to estimate state and national totals for annual carbon sequestration.

\subsection{Overlap with forest estimates}

As national forestland (FIA) data contains data from forest stands in urban areas, and the national urban forest data contains data from forest stands in urban areas, there is an overlap between the two estimates. This overlap leads to doublecounting carbon when combining the two estimates for national scale analyses. To estimate the amount of overlap between urban forest and forestland estimates, urban boundaries were overlaid on national FIA plot locations using a geographic information system. Each FIA plot was classified as to whether the plot was $100 \%$ forested, partially forested (data were collected only on forested portions of the 4 sub-plots) or $100 \%$ non-forest (no data collected).

To estimate the number of FIA plots where data were collected in urban areas within a state, $100 \%$ of forested plots were assumed to be sampled, non-forest plots were assumed to be not sampled by field crews, and the number of partial forest plots sampled was estimated as number of partial plots times the average percent urban tree cover in the state (e.g., if tree cover was $50 \%$, then half of the partial forest plots were assumed to be measured). The number of FIA plots measured in urban areas was contrasted with the total number of FIA plots measured in each state to determine the proportion of FIA plots sampled in urban areas.

\section{Results}

Average carbon storage per square meter of tree cover varies by sampled city and state (Table 2 ), with overall carbon storage averaging $7.69 \mathrm{~kg} \mathrm{C} \mathrm{m}^{-2}(\mathrm{SE}=1.36)$, gross carbon sequestration rate averaging $0.277 \mathrm{~kg} \mathrm{C} \mathrm{m}^{-2}$ year $^{-1}(\mathrm{SE}=0.045)$, and net carbon sequestration rate averaging $0.205 \mathrm{~kg} \mathrm{C} \mathrm{m}^{-2}$ year $^{-1}(\mathrm{SE}=0.041)$. The net sequestration rate averages $74 \%$ of the gross sequestration rate. Total carbon storage and sequestration rates in urban and urban/community areas also varied among the United States (Table 3) with total urban tree carbon storage estimated as 643 million tonnes ( $\mathrm{SE}=23.8$ million; value $=\$ 50.5$ billion $)$ and total urban/community tree carbon storage estimated as 1.36 billion tonnes ( $\mathrm{SE}=57.0$ million; value $=\$ 106.9$ billion). Annual gross carbon sequestration is 25.6 million tonnes $\operatorname{year}^{-1}(\mathrm{SE}=1.0$ million; value $=\$ 2.0$ billion) in urban areas and 50.3 million tonnes year $^{-1}$ in urban/community areas $(\mathrm{SE}=1.8$ million; value $=\$ 4.0$ billion). Annual net carbon sequestration is 18.9 million tonnes year $^{-1}(\mathrm{SE}=862,000$; value $=\$ 1.5$ billion $)$ in urban and 37.2 million tonnes year $^{-1}$ in urban/community areas $(\mathrm{SE}=1.7$ million; value $=\$ 2.9$ billion). However, it should be noted that Alaska contains $17 \%$ of the total U.S. urban/community area due to its relatively large community boundaries. If urban/community estimates focus on the conterminous United States, the carbon storage, annual gross sequestration and annual net sequestration estimates drop to 1.1 billion, 44.7 million, and 33.1 million tonnes, respectively (Table 3 ).

In terms of national overlap between conterminous U.S. forestland estimates and urban forest estimates, $13.7 \%$ of urban land, or about $38.6 \%$ of all urban tree cover, is measured by the U.S. forest inventory plots. From the national forest plot perspective, about $1.5 \%$ of all forestland plots are in urban areas in the 
Table 2

Standardized carbon storage and sequestration estimates per unit of tree cover and percent tree cover in measured cities and states.

\begin{tabular}{|c|c|c|c|c|c|c|c|c|}
\hline \multirow[t]{2}{*}{ City/State } & \multicolumn{2}{|l|}{ Storage } & \multicolumn{2}{|c|}{ Gross sequestration } & \multicolumn{2}{|c|}{ Net sequestration } & \multicolumn{2}{|c|}{ Tree cover } \\
\hline & $\mathrm{kg} \mathrm{C} \mathrm{m}{ }^{-2}$ & $\mathrm{SE}$ & $\begin{array}{l}\mathrm{kg} \mathrm{C} \mathrm{m} \\
\text { year }^{-1}\end{array}$ & $\mathrm{SE}$ & $\begin{array}{l}\mathrm{kg} \mathrm{C} \mathrm{m}^{-2} \\
\text { year }^{-1}\end{array}$ & $\mathrm{SE}$ & $\%$ & $\overline{\mathrm{SE}}$ \\
\hline Arlington, TX & 6.37 & 0.73 & 0.288 & 0.028 & 0.262 & 0.025 & 22.5 & 0.3 \\
\hline Atlanta, GA & 6.63 & 0.54 & 0.229 & 0.017 & 0.175 & 0.025 & 53.9 & 1.6 \\
\hline Baltimore, MD & 8.76 & 1.09 & 0.282 & 0.036 & 0.168 & 0.032 & 28.5 & 1.0 \\
\hline Boston, MA & 7.02 & 0.96 & 0.231 & 0.025 & 0.168 & 0.023 & 28.9 & 1.5 \\
\hline Casper, WY & 6.97 & 1.50 & 0.221 & 0.039 & 0.119 & 0.038 & 8.9 & 1.0 \\
\hline Chicago, IL & 6.03 & 0.64 & 0.212 & 0.021 & 0.149 & 0.018 & 18.0 & 1.2 \\
\hline Freehold, NJ & 11.50 & 1.78 & 0.314 & 0.045 & 0.201 & 0.050 & 31.2 & 3.3 \\
\hline Gainesville, FL & 6.33 & 0.99 & 0.220 & 0.032 & 0.160 & 0.025 & 50.6 & 3.1 \\
\hline Golden, CO & 5.88 & 1.33 & 0.228 & 0.045 & 0.181 & 0.038 & 11.4 & 1.5 \\
\hline Hartford, CT & 10.89 & 1.62 & 0.329 & 0.046 & 0.186 & 0.051 & 26.2 & 2.0 \\
\hline Jersey City, NJ & 4.37 & 0.88 & 0.183 & 0.034 & 0.132 & 0.035 & 11.5 & 1.7 \\
\hline Lincoln, NE & 10.64 & 1.74 & 0.409 & 0.063 & 0.351 & 0.055 & 14.4 & 1.6 \\
\hline Los Angeles, CA & 4.59 & 0.51 & 0.176 & 0.017 & 0.107 & 0.015 & 20.6 & 1.3 \\
\hline Milwaukee, WI & 7.26 & 1.18 & 0.260 & 0.033 & 0.178 & 0.027 & 21.6 & 1.6 \\
\hline Minneapolis, MN & 4.41 & 0.74 & 0.157 & 0.023 & 0.081 & 0.045 & 34.1 & 1.6 \\
\hline Moorestown, NJ & 9.95 & 0.93 & 0.320 & 0.030 & 0.241 & 0.028 & 28.0 & 1.6 \\
\hline Morgantown, WV & 9.52 & 1.16 & 0.297 & 0.037 & 0.231 & 0.026 & 39.6 & 2.2 \\
\hline New York, NY & 7.33 & 1.01 & 0.230 & 0.029 & 0.124 & 0.028 & 20.9 & 1.3 \\
\hline Oakland, CA & 5.24 & 0.19 & na & na & na & na & 21.0 & 0.2 \\
\hline Omaha, NE & 14.14 & 2.29 & 0.513 & 0.081 & 0.401 & 0.066 & 14.8 & 1.6 \\
\hline Philadelphia, PA & 6.77 & 0.90 & 0.206 & 0.027 & 0.151 & 0.023 & 20.8 & 1.8 \\
\hline Roanoke, VA & 9.20 & 1.33 & 0.399 & 0.058 & 0.268 & 0.053 & 31.7 & 3.3 \\
\hline Sacramento, CA & 7.82 & 1.57 & 0.377 & 0.064 & 0.327 & 0.055 & 13.2 & 1.7 \\
\hline San Francisco, CA & 9.18 & 2.25 & 0.241 & 0.050 & 0.221 & 0.046 & 16.0 & 2.6 \\
\hline Scranton, PA & 9.24 & 1.28 & 0.399 & 0.052 & 0.296 & 0.043 & 22.0 & 1.9 \\
\hline Syracuse, NY & 8.59 & 1.04 & 0.285 & 0.030 & 0.202 & 0.039 & 26.9 & 1.3 \\
\hline Washington, $\mathrm{DC}^{\mathrm{a}}$ & 8.52 & 1.04 & 0.263 & 0.030 & 0.209 & 0.026 & 35.0 & 2.0 \\
\hline Woodbridge, NJ & 8.19 & 0.82 & 0.285 & 0.028 & 0.208 & 0.029 & 29.5 & 1.7 \\
\hline Indiana & 8.80 & 2.68 & 0.292 & 0.077 & 0.270 & 0.071 & 20.1 & 3.2 \\
\hline Kansas & 7.42 & 1.30 & 0.284 & 0.048 & 0.221 & 0.040 & 14.0 & 1.6 \\
\hline Nebraska & 6.67 & 1.86 & 0.269 & 0.074 & 0.227 & 0.063 & 15.0 & 3.6 \\
\hline North Dakota & 7.78 & 2.47 & 0.282 & 0.079 & 0.134 & 0.079 & 2.7 & 0.6 \\
\hline South Dakota & 3.14 & 0.66 & 0.128 & 0.026 & 0.111 & 0.022 & 16.5 & 2.2 \\
\hline Tennessee & 6.47 & 0.50 & 0.340 & 0.021 & 0.304 & 0.020 & 37.7 & 0.8 \\
\hline
\end{tabular}

na - not analyzed.

a Tree cover estimated based on high resolution tree cover map of city with an estimated standard error of 2 percent.

conterminous U.S. (9.3 million ha) (Table 4). Carbon storage that is accounted for in both the national forestland and urban forest estimates ranges from 247 million tonnes using the $38.6 \%$ urban overlap estimate to 303 million tonnes using the $1.5 \%$ national forestland overlap estimate.

\section{Discussion}

Trees and forests in U.S. urban areas (circa 2005) store 643 million tonnes of carbon (639 million tonnes of carbon in the conterminous U.S.). This new estimate is within range of past estimates for the conterminous U.S. (circa 1990 estimate $=700$ million tonnes; Nowak and Crane, 2002), but due to the new data, the current estimate has a reduced bound of error. The $95 \%$ confidence interval $(\mathrm{CI})$ for the current carbon storage estimate is between 597 million and 690 million tonnes. However, this bound of estimate is conservative as the error estimate is based on sampling error, and does not include estimation error. If community land is combined with the urban land, the total estimate rises to 1.36 billion tonnes with a $95 \% \mathrm{CI}$ between 1.25 and 1.47 billion tonnes. The relative standard error (SE/total) for carbon storage in urban areas varied among the states from 0.18 to 0.37 . Most of this variation is due to differences in SE of tree cover estimates as states had variable sample sizes in estimating tree cover.

Given the potential available space (pervious land) in urban areas of $74.5 \%$ or 17.7 million ha (Nowak and Greenfield, 2012b), carbon storage could increase in the United States. However, given the limitations to tree growth and establishment in urban areas imposed by humans (e.g., mowing) and nature (e.g., lack of precipitation), increasing carbon storage in urban areas is not likely without a major effort to change current conditions (both social and physical). As tree cover in urban areas in the United States is on the decline (Nowak and Greenfield, 2012a), carbon storage in urban areas are also likely on the decline. Long-term monitoring of urban forests is needed to better understand rates of changes in urban areas and provide better estimates of long-term carbon trends.

Carbon storage by trees in forestlands nationally was 20.2 billion tonnes in 2008 (Heath et al., 2011). Given the overlap between urban and U.S. forestland estimates for above and below-ground carbon in trees, total U.S. tree carbon storage including urban and forestland areas is estimated at 20.6 billion tonnes. Carbon storage by urban trees nationally is about $3.2 \%$ of the estimated carbon stored in U.S. forestland and urban forest trees combined.

Urban tree carbon storage and sequestration in a state is a function of the total amount of urban tree cover. Generally, states in forested regions have higher percent urban tree cover than urban areas in grassland or desert regions (Nowak et al., 2001; Nowak and Greenfield, 2012b). Thus forested regions will typically have the greatest urban forest carbon densities per unit land area. Carbon density per unit of tree cover range from 3.1 to $14.1 \mathrm{~kg} \mathrm{C} \mathrm{m}^{-2}$ and have less variation than carbon estimates per unit of land cover. The carbon per unit of tree cover varies among cities based on variations in tree density, tree size distributions, and species composition.

The estimated rate of carbon storage per square meter of tree cover has decreased from $9.25 \mathrm{~kg} \mathrm{C} \mathrm{m}^{-2}$ (Nowak and Crane, 2002) to $7.69 \mathrm{~kg} \mathrm{C} \mathrm{m}^{-2}$. This reduction is due to an increased availability of data and better tree cover estimates derived from photo- 
Table 3

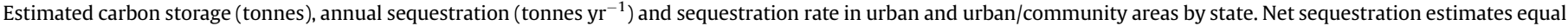
$74 \%$ of gross sequestration.

\begin{tabular}{|c|c|c|c|c|c|c|c|c|c|}
\hline \multirow[t]{2}{*}{ State } & \multicolumn{4}{|c|}{ Storage $\left(\times 10^{6}\right)$} & \multicolumn{4}{|c|}{ Gross sequestration $\left(\mathrm{x} 10^{3}\right)$} & \multirow[t]{2}{*}{ Rate $^{b}$} \\
\hline & Urban & SE & $\mathrm{UC}^{\mathrm{a}}$ & SE & Urban & SE & $\mathrm{UC}^{\mathrm{a}}$ & SE & \\
\hline Alabama (AL) & 18.7 & 3.6 & 53.9 & 9.8 & 836 & 148 & 2406 & 402 & 0.343 \\
\hline Arizona (AZ) & 5.5 & 1.4 & 21.3 & 4.3 & 253 & 64 & 981 & 185 & 0.354 \\
\hline Arkansas (AR) & 7.7 & 1.6 & 20.0 & 3.9 & 331 & 66 & 858 & 154 & 0.331 \\
\hline California (CA) & 31.4 & 6.0 & 66.9 & 12.3 & 1591 & 283 & 3386 & 571 & 0.389 \\
\hline Colorado (CO) & 4.4 & 1.2 & 10.0 & 2.3 & 112 & 30 & 257 & 55 & 0.197 \\
\hline Connecticut (CT) & 23.3 & 4.3 & 26.0 & 4.8 & 724 & 123 & 806 & 136 & 0.239 \\
\hline Delaware (DE) & 2.3 & 0.5 & 2.4 & 0.5 & 99 & 21 & 106 & 22 & 0.335 \\
\hline Florida (FL) & 42.9 & 8.0 & 62.6 & 11.4 & 2650 & 455 & 3864 & 649 & 0.475 \\
\hline Georgia (GA) & 38.5 & 7.1 & 60.0 & 10.9 & 1770 & 299 & 2759 & 458 & 0.353 \\
\hline Idaho (ID) & 1.1 & 0.3 & 1.4 & 0.5 & 25 & 8 & 33 & 11 & 0.184 \\
\hline Illinois (IL) & 18.7 & 3.7 & 24.4 & 4.7 & 688 & 128 & 896 & 161 & 0.283 \\
\hline Indiana (IN) & 9.7 & 2.2 & 13.7 & 2.9 & 317 & 67 & 447 & 88 & 0.250 \\
\hline Iowa (IA) & 3.8 & 1.0 & 7.7 & 1.8 & 117 & 28 & 240 & 52 & 0.240 \\
\hline Kansas (KS) & 4.8 & 1.1 & 7.3 & 1.8 & 176 & 40 & 270 & 62 & 0.283 \\
\hline Kentucky (KY) & 6.5 & 1.6 & 9.0 & 2.0 & 241 & 55 & 334 & 72 & 0.286 \\
\hline Louisiana (LA) & 10.6 & 2.2 & 20.4 & 4.0 & 544 & 109 & 1052 & 191 & 0.397 \\
\hline Maine (ME) & 3.8 & 0.8 & 13.6 & 2.7 & 109 & 20 & 390 & 71 & 0.221 \\
\hline Maryland (MD) & 11.9 & 2.5 & 15.6 & 3.1 & 497 & 98 & 655 & 123 & 0.323 \\
\hline Massachusetts (MA) & 35.9 & 6.6 & 41.1 & 7.5 & 1187 & 199 & 1359 & 227 & 0.254 \\
\hline Michigan (MI) & 22.9 & 4.5 & 28.9 & 5.5 & 654 & 118 & 826 & 146 & 0.220 \\
\hline Minnesota (MN) & 9.3 & 2.0 & 27.7 & 5.3 & 275 & 55 & 825 & 145 & 0.229 \\
\hline Mississippi (MI) & 7.4 & 1.6 & 20.6 & 4.0 & 333 & 67 & 922 & 164 & 0.344 \\
\hline Missouri (MS) & 11.2 & 2.4 & 20.2 & 4.0 & 417 & 83 & 750 & 138 & 0.285 \\
\hline Montana (MT) & 0.5 & 0.2 & 21.5 & 4.2 & 11 & 4 & 514 & 94 & 0.184 \\
\hline Nebraska (NE) & 1.6 & 0.4 & 2.2 & 0.7 & 51 & 13 & 68 & 20 & 0.238 \\
\hline Nevada (NV) & 1.3 & 0.4 & 5.8 & 1.5 & 35 & 11 & 155 & 39 & 0.207 \\
\hline New Hampshire (NH) & 7.1 & 1.4 & 12.2 & 2.3 & 202 & 36 & 344 & 61 & 0.217 \\
\hline New Jersey (NJ) & 28.0 & 5.3 & 34.8 & 6.4 & 1069 & 186 & 1328 & 227 & 0.294 \\
\hline New Mexico (NM) & 1.8 & 0.6 & 4.9 & 1.3 & 62 & 19 & 166 & 44 & 0.263 \\
\hline New York (NY) & 32.1 & 6.0 & 43.2 & 7.9 & 1005 & 175 & 1350 & 229 & 0.240 \\
\hline North Carolina (NC) & 34.0 & 6.3 & 51.0 & 9.3 & 1378 & 236 & 2067 & 346 & 0.312 \\
\hline North Dakota (ND) & 0.4 & 0.1 & 1.6 & 0.5 & 12 & 4 & 46 & 14 & 0.223 \\
\hline Ohio $(\mathrm{OH})$ & 22.9 & 4.5 & 32.3 & 6.1 & 739 & 134 & 1038 & 182 & 0.248 \\
\hline Oklahoma (OK) & 4.3 & 1.1 & 29.1 & 5.5 & 187 & 46 & 1256 & 221 & 0.332 \\
\hline Oregon (OR) & 8.1 & 1.8 & 10.8 & 2.3 & 255 & 52 & 339 & 67 & 0.242 \\
\hline Pennsylvania (PA) & 28.7 & 5.5 & 45.4 & 8.4 & 911 & 161 & 1438 & 245 & 0.244 \\
\hline Rhode Island (RI) & 4.1 & 0.8 & 4.2 & 0.8 & 139 & 26 & 140 & 27 & 0.258 \\
\hline South Carolina (SC) & 17.3 & 3.4 & 27.1 & 5.1 & 760 & 138 & 1190 & 206 & 0.338 \\
\hline South Dakota (SD) & 0.7 & 0.2 & 1.8 & 0.6 & 21 & 5 & 56 & 17 & 0.236 \\
\hline Tennessee (TN) & 18.9 & 3.7 & 38.2 & 7.1 & 744 & 136 & 1508 & 259 & 0.303 \\
\hline Texas (TX) & 45.2 & 8.4 & 81.4 & 14.8 & 2165 & 370 & 3897 & 650 & 0.368 \\
\hline Utah (UT) & 2.1 & 0.6 & 7.5 & 1.8 & 58 & 17 & 210 & 47 & 0.215 \\
\hline Vermont (VT) & 1.5 & 0.3 & 2.8 & 0.6 & 42 & 8 & 77 & 15 & 0.213 \\
\hline Virginia (VA) & 16.6 & 3.3 & 30.9 & 5.8 & 632 & 117 & 1174 & 204 & 0.293 \\
\hline Washington (WA) & 13.8 & 2.8 & 23.8 & 4.6 & 463 & 89 & 799 & 143 & 0.258 \\
\hline West Virginia (WV) & 5.1 & 1.1 & 12.0 & 2.3 & 161 & 31 & 376 & 68 & 0.241 \\
\hline Wisconsin (WI) & 9.4 & 2.1 & 19.2 & 3.8 & 275 & 57 & 562 & 102 & 0.225 \\
\hline Wyoming (WY) & 0.3 & 0.1 & 7.4 & 1.7 & 7 & 3 & 175 & 39 & 0.182 \\
\hline US $48^{c}$ & 638.8 & 23.8 & 1126.1 & 38.9 & 25,347 & 955 & 44,711 & 1563 & 0.305 \\
\hline Alaska & 2.0 & 0.4 & 225.8 & 41.7 & 44 & 7 & 4945 & 840 & 0.168 \\
\hline Hawaii & 2.2 & 0.4 & 9.0 & 1.6 & 167 & 28 & 682 & 112 & 0.581 \\
\hline $\mathrm{US}^{\mathrm{d}}{ }^{\mathrm{d}}$ & 643.2 & 23.8 & 1361.2 & 57.0 & 25,559 & 956 & 50,338 & 1778 & 0.306 \\
\hline
\end{tabular}

${ }^{\text {a }}$ Urban/community land.

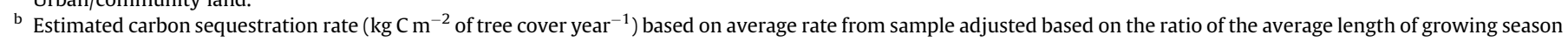
in each state to sample average length of growing season.

c Conterminous United States.

d 50 states.

interpretation. Storage rates per square meter of tree cover in urban areas $\left(7.69 \mathrm{~kg} \mathrm{C} \mathrm{m}^{-2}\right)$ are slightly larger than those found within forestlands (7.24 $\mathrm{kg} \mathrm{C} \mathrm{m}^{-2}$ ) (Heath et al., 2011). However, this forestland estimate assumes $100 \%$ tree cover, which is likely leading to an underestimate of carbon storage per unit of tree cover.

Carbon density rates in this study vary substantially among cities/states from 3.14 to $14.1 \mathrm{~kg} \mathrm{C} \mathrm{m}^{-2}$ cover. This wide range in values illustrates the importance of local forest structure on carbon densities and the need for more local data to refine estimates. This range in values has been illustrated in other studies as well. In the Seattle, WA region, above-ground live carbon storage has been estimated at $8.9 \mathrm{~kg} \mathrm{C} \mathrm{m}^{-2}$ with $57 \%$ tree cover, which equates to $15.6 \mathrm{~kg} \mathrm{C} \mathrm{m}^{-2}$ of tree cover. These regional values are greater than the urban estimates in our study as the regional values include significant amounts of peri-urban forest stands. When focused on the urban lands, estimates were $0.2 \mathrm{~kg} \mathrm{C} \mathrm{m}^{-2}$ in heavy urban land uses (6\% tree cover; or $3.3 \mathrm{~kg} \mathrm{C} \mathrm{m}^{-2}$ of tree cover); $1.5 \mathrm{~kg} \mathrm{C} \mathrm{m}^{-2}$ in medium urban land uses (21\% tree cover; or $7.1 \mathrm{~kg} \mathrm{C} \mathrm{m}^{-2}$ of tree cover); and $3.6 \mathrm{~kg} \mathrm{C} \mathrm{m}^{-2}$ in low urban land uses (31\% tree cover; or $11.6 \mathrm{~kg} \mathrm{C} \mathrm{m}^{-2}$ of tree cover) (Hutyra et al., 2011). Storage values in our study are comparable to the medium urban land uses in the Seattle region. 
Table 4

Statistics on U.S. forestland plots within urban areas by state.

\begin{tabular}{|c|c|c|c|c|c|c|c|}
\hline State & $\begin{array}{l}\text { Forest } \\
\text { plots }^{\mathrm{a}}\end{array}$ & $\begin{array}{l}\text { Urban } \\
\text { plots }^{\text {b }}\end{array}$ & $\begin{array}{l}\text { Partial } \\
\text { forest }(\%)^{c}\end{array}$ & $\begin{array}{l}100 \% \text { forest } \\
(\%)^{c}\end{array}$ & $\begin{array}{l}\text { Urban forest } \\
\text { plots }^{\mathrm{d}}\end{array}$ & $\begin{array}{l}\text { Urban } \\
\text { forest }(\%)^{\mathrm{e}}\end{array}$ & $\begin{array}{l}\text { Forest in } \\
\text { urban }(\%)^{\mathrm{f}}\end{array}$ \\
\hline$\overline{A L}$ & 3614 & 177 & 16.9 & 10.7 & 35 & 19.7 & 1.0 \\
\hline AR & 2804 & 97 & 17.5 & 6.2 & 13 & 13.7 & 0.5 \\
\hline$A Z^{g}$ & 2373 & 159 & 44.7 & 1.9 & 15 & 9.2 & 0.6 \\
\hline $\mathrm{CA}^{\mathrm{g}}$ & 4064 & 765 & 3.5 & 0.8 & 11 & 1.5 & 0.3 \\
\hline $\mathrm{CO}^{\mathrm{g}}$ & 2312 & 107 & 50.5 & 0.9 & 10 & 9.7 & 0.4 \\
\hline $\mathrm{CT}$ & 283 & 181 & 27.6 & 15.5 & 61 & 33.8 & 21.6 \\
\hline $\mathrm{DE}$ & 57 & 28 & 10.7 & 3.6 & 2 & 7.6 & 3.8 \\
\hline FL & 2497 & 679 & 11.0 & 5.4 & 63 & 9.3 & 2.5 \\
\hline GA & 3849 & 419 & 26.3 & 9.3 & 96 & 23.0 & 2.5 \\
\hline IA & 269 & 96 & 8.3 & 3.1 & 5 & 5.1 & 1.8 \\
\hline $\mathrm{ID}^{\mathrm{g}}$ & 2010 & 22 & 81.8 & 0.0 & 2 & 10.6 & 0.1 \\
\hline IL & 472 & 385 & 7.0 & 3.6 & 21 & 5.5 & 4.5 \\
\hline IN & 543 & 245 & 8.2 & 2.9 & 11 & 4.7 & 2.1 \\
\hline KS & 157 & 94 & 8.5 & 0.0 & 2 & 2.4 & 1.4 \\
\hline KY & 1933 & 131 & 13.0 & 6.9 & 14 & 10.4 & 0.7 \\
\hline LA & 2110 & 189 & 14.3 & 5.8 & 20 & 10.4 & 0.9 \\
\hline MA & 488 & 302 & 28.1 & 16.9 & 106 & 35.0 & 21.7 \\
\hline MD & 338 & 194 & 22.7 & 13.4 & 40 & 20.9 & 12.0 \\
\hline ME & 3027 & 37 & 54.1 & 2.7 & 12 & 31.9 & 0.4 \\
\hline MI & 2897 & 365 & 11.5 & 4.7 & 32 & 8.6 & 1.1 \\
\hline MN & 2224 & 163 & 11.7 & 0.6 & 7 & 4.2 & 0.3 \\
\hline MO & 2068 & 191 & 11.0 & 4.2 & 15 & 7.6 & 0.7 \\
\hline MS & 3004 & 96 & 29.2 & 6.2 & 17 & 18.2 & 0.6 \\
\hline $\mathrm{MT}^{\mathrm{g}}$ & 2805 & 21 & 76.2 & 0.0 & 1 & 6.9 & 0.1 \\
\hline NC & 2912 & 398 & 26.6 & 7.5 & 81 & 20.4 & 2.8 \\
\hline ND & 70 & 17 & 0.0 & 0.0 & 0 & 0.0 & 0.0 \\
\hline $\mathrm{NE}$ & 132 & 51 & 2.0 & 0.0 & 0 & 0.4 & 0.1 \\
\hline $\mathrm{NH}$ & 847 & 65 & 43.1 & 20.0 & 31 & 47.6 & 3.7 \\
\hline $\mathrm{NJ}$ & 308 & 306 & 19.9 & 8.5 & 57 & 18.5 & 18.4 \\
\hline $\mathrm{NM}^{\mathrm{h}}$ & 1308 & 81 & na & na & 4 & 12.0 & 0.7 \\
\hline $\mathrm{NV}^{\mathrm{g}}$ & 339 & 14 & 0.0 & 0.0 & 0 & 0.0 & 0.0 \\
\hline NY & 2932 & 422 & 21.1 & 8.3 & 72 & 17.0 & 2.4 \\
\hline $\mathrm{OH}$ & 1138 & 424 & 20.8 & 6.6 & 54 & 12.6 & 4.7 \\
\hline OK & 902 & 42 & 19.0 & 4.8 & 4 & 8.4 & 0.4 \\
\hline $\mathrm{OR}^{\mathrm{g}}$ & 2890 & 110 & 20.0 & 2.7 & 12 & 10.7 & 0.4 \\
\hline PA & 2548 & 456 & 20.2 & 5.5 & 56 & 12.3 & 2.2 \\
\hline RI & 62 & 44 & 34.1 & 4.5 & 10 & 23.0 & 16.3 \\
\hline SC & 2036 & 207 & 23.7 & 11.1 & 46 & 22.3 & 2.3 \\
\hline SD & 238 & 17 & 0.0 & 5.9 & 1 & 5.9 & 0.4 \\
\hline $\mathrm{TN}$ & 2211 & 257 & 66.9 & 10.5 & 94 & 36.7 & 4.3 \\
\hline TX & 4839 & 541 & 10.0 & 5.9 & 49 & 9.1 & 1.0 \\
\hline $\mathrm{UT}^{\mathrm{g}}$ & 2215 & 74 & 44.6 & 0.0 & 5 & 6.7 & 0.2 \\
\hline VA & 2569 & 262 & 17.9 & 6.9 & 34 & 13.1 & 1.3 \\
\hline VT & 757 & 18 & 16.7 & 11.1 & 4 & 19.9 & 0.5 \\
\hline$W^{g}$ & 1531 & 191 & 53.9 & 1.6 & 37 & 19.3 & 2.4 \\
\hline WI & 2303 & 192 & 12.0 & 1.6 & 10 & 5.1 & 0.4 \\
\hline WV & 1957 & 69 & 30.4 & 8.7 & 16 & 23.0 & 0.8 \\
\hline$W Y^{h}$ & 789 & 20 & na & na & 1 & 9.0 & 0.2 \\
\hline$U S^{i}$ & 84,031 & 9421 & 19.9 & 6.1 & 1289 & 13.8 & 1.5 \\
\hline
\end{tabular}

a Estimated number of forested plots.

b Total plots laid in urban areas.

c Percent of urban plots.

d Estimated number of urban plots that were measured.

e Percent of urban plots laid that are forested (urban forest plots/urban plots).

f Percent of forest plots within urban areas (urban forest plots/forest plots).

g Not all plots sampled to date. Numbers given are for plots with completed data collection. On average, about $76 \%$ of the plots have been measured in these western states.

h No plot data collected to date. Numbers given are based on all state plots (unsampled). Estimate of urban plots that will have data collection ( $<0.1 \%$ of all plots) assume that urban plots are partially forested proportional to urban tree cover in state.

i Conterminous United States.

In three cities in middle Korea: Chuncheon, Kangleung, and Seoul, mean carbon storage by woody plants ranged from 0.47 to $0.72 \mathrm{~kg} \mathrm{C} \mathrm{m}^{-2}$ for urban lands (Jo, 2002), which equates to 3.85$5.58 \mathrm{~kg} \mathrm{C} \mathrm{m}^{-2}$ of tree cover. Annual carbon sequestration values in these urban areas ranged from 0.41 to $0.62 \mathrm{~kg} \mathrm{C} \mathrm{m}^{-2}$ of tree cover year $^{-1}$. Values in more natural land uses in Korea ranged from 2.6 to $5.87 \mathrm{~kg} \mathrm{C} \mathrm{m}^{-2}$ of tree cover for carbon storage and $0.16-$ $0.39 \mathrm{~kg} \mathrm{C} \mathrm{m}^{-2}$ of tree cover year ${ }^{-1}$ for sequestration assuming $100 \%$ tree cover in these areas. The storage values are slightly lower than the U.S. urban average likely due to differences in forest structure.
Annual sequestration rate per unit of tree cover are higher likely due to higher growth rates compared to the U.S. average.

In Leipzig, Germany, carbon storage averaged $6.82 \mathrm{~kg} \mathrm{C} \mathrm{m}^{-2}$ of tree cover, but varied from $0.68 \mathrm{~kg} \mathrm{C} \mathrm{m}^{-2}$ of tree cover in afforestation areas to $9.85 \mathrm{~kg} \mathrm{C} \mathrm{m}^{-2}$ of tree cover in riparian forests (Strohbach and Haase, 2012). In Barcelona, Spain, carbon storage averaged $4.45 \mathrm{~kg} \mathrm{C} \mathrm{m}^{-2}$ of tree cover, but varied from $1.53 \mathrm{~kg} \mathrm{C} \mathrm{m}^{-2}$ of tree cover in commercial/industrial areas to $9.67 \mathrm{~kg} \mathrm{C} \mathrm{m}^{-2}$ of tree cover in institutional areas (Chaparro and Terradas, 2009). In Hangzhou, China, carbon storage averaged $4.28 \mathrm{~kg} \mathrm{C} \mathrm{m}^{-2}$ of tree 
cover (Zhao et al., 2010). Within urban areas of the Boston metropolitan area, above-ground carbon storage (live trees, $\mathrm{dbh}>5 \mathrm{~cm}$ ) was estimated at $10.6 \mathrm{~kg} \mathrm{C} \mathrm{m}^{-2}$ of tree cover (Raciti et al., 2012). This value is higher than the national average, but within the range from other U.S. cities (Table 2).

Carbon density rates in this national study (maximum rate of $14.1 \mathrm{~kg} \mathrm{C} \mathrm{m}^{-2}$ cover) are substantially lower than the maximum above-ground carbon density for all vegetation in treed areas in Leicester, England (28.1-28.9 $\mathrm{kg} \mathrm{C} \mathrm{m}^{-2}$ ) (Davies et al., 2011) and estimates for total carbon within human settlements (23$42 \mathrm{~kg} \mathrm{C} \mathrm{m}^{-2}$ ) (Churkina et al., 2010). The human settlement estimates are higher because they account for all carbon (e.g., vegetation, buildings); the Leicester tree estimate could be higher due to increased tree densities (Davies, pers. comm., 2012).

Total annual urban gross carbon sequestration is estimated at 25.6 million tonnes year ${ }^{-1}(95 \% \mathrm{CI}=23.7$ million-27.4 million tonnes). Total annual urban net carbon sequestration is estimated at 18.9 million tonnes year ${ }^{-1}(95 \% \mathrm{CI}=17.2$ million-20.6 million tonnes). Urban tree carbon sequestration rates per square meter of tree cover $\left(0.28 \mathrm{~kg} \mathrm{C} \mathrm{m}^{-2}\right.$ year $\left.^{-1}\right)$ from the sampled cities and states fall within range of estimated sequestration rates for the first 15 years of afforestation of crop and pasture land $\left(0.18-0.43 \mathrm{~kg} \mathrm{C} \mathrm{m}^{-2}\right.$ year $^{-1}$ ) (Lewandrowski et al., 2004). The national average gross sequestration rate per square meter of tree cover is estimated at $0.306 \mathrm{~kg} \mathrm{C} \mathrm{m}^{-2}$ year $^{-1}$, but varies among the states from 0.168 to $0.581 \mathrm{~kg} \mathrm{C} \mathrm{m}^{-2}$ year $^{-1}$ based on length of growing season (Table 3 ). The net sequestration is estimated at $0.226 \mathrm{~kg} \mathrm{C} \mathrm{m}^{-2}$ year ${ }^{-1}$. Sequestration rates will vary locally based on tree sizes, tree health, and growth rates associated with species and site conditions. Net annual carbon sequestration is positive for growing forests, but sequestration rates will diminish through time as the forest matures. The sequestration will become negative during periods of forest decline and/or loss when carbon emissions from dead trees (e.g., decomposition, fire) exceed carbon uptake by live trees.

The carbon estimates are based on available data from select cities and states, not a random sample of urban areas. However, the standardization of carbon values per unit tree cover allows these standard values to be applied to actual tree cover within an area to provide a reasonable estimate of carbon storage and sequestration. The estimates are reasonable as they are based on, and therefore account for, local tree cover values and local growth rates. State level results would vary from the given estimates if tree diameter distribution, tree density, and to a lesser extent, species composition, varied from the national average per unit of tree cover. Local and national estimates can be improved through field data collection to estimate local forest structure and carbon storage and sequestration.

In addition to direct carbon storage and sequestration reported in this paper, urban trees can also affect carbon emissions in urban areas. Planting trees in energy-conserving locations around buildings (e.g., Heisler, 1986) can reduce building energy use and consequently emissions from power plants. Transpirational cooling and changes in albedo due to trees alters urban microclimates that can also reduce carbon emissions from cities (e.g., reduced evaporative emissions with lower air temperatures). Additionally, urban tree management practices need to be considered when estimating the net effects of urban trees on atmospheric $\mathrm{CO}_{2}$ as various maintenance activities emit carbon back to the atmosphere via fossil-fuel combustion (e.g., from chain saws, trucks, chippers) (Nowak et al., 2002). As urban areas produce substantial emissions of carbon, tree effects on carbon emissions through altering of microclimates, albedo, energy use, and maintenance emissions need to be incorporated with tree storage and sequestration estimates to develop a more complete assessment of the role of urban forests on climate change.
Urban soils are estimated to store approximately 1.9 billion tonnes of carbon in the United States (Pouyat et al., 2006), three times more than urban trees. More research is needed on the cumulative effects of trees, soils and their management in urban areas (e.g., Pataki et al., 2006) though carbon estimates for urban ecosystems are improving through time as new data become available. Monitoring of urban and other non-forest areas will help improve carbon estimates in urban and other traditionally non-forested landscapes. A better understanding and accounting of urban ecosystems can be used to develop management plans and national policies that can significantly improve environmental quality and human health across the nation.

\section{Acknowledgments}

Funding for this project was provided, in part, by the USDA Forest Service's RPA Assessment Staff and State and Private Forestry's Urban and Community Forestry Program and the National Science Foundation (NSF grants DEB-0423476 and BCS-0948952) through the Baltimore Ecosystem Study-Long Term Ecological Research (BES-LTER) and the Syracuse Urban Long-term Research Area Exploratory Award (ULTRA-Ex). The authors thank the numerous people and organizations involved with field data collection. The authors also thank John Stanovick for his statistical assistance and review, and Linda Heath, Mark Flugge, Nicholas Devonshire and Jennifer Jenkins for their comments on a draft manuscript.

\section{References}

Abdollahi, K.K., Ning, Z.H., Appeaning, A., 2000. Global Climate Change and the Urban Forest. GCRCC and Franklin Press, Baton Rouge, pp. 31-44.

Brack, C.L., 2002. Pollution mitigation and carbon sequestration by an urban forest. Environmental Pollution 116 (Suppl. 1), 195-200.

Chaparro, L., Terradas, J., 2009. Ecological Services of Urban Forest in Barcelona. Àrea de Medi Ambient Institut Municipal de Parcs i Jardins, Ajuntament de Barcelona.

Churkina, G., Brown, D., Keoleian, G., 2010. Carbon stored in human settlements: the conterminous United States. Global Change Biology 16 (1), 135-143.

Cumming, A.B., Twardus, D.B., Nowak, D.J., 2008. Urban forest health monitoring: large scale assessments in the United States. Arboriculture and Urban Forestry 34 (6), 341-346.

Davies, Z.G., personal communication, 2012. Department of Animal and Plant Sciences, University of Sheffield, Sheffield, UK.

Davies, Z.G., Edmonson, J.L., Heinemeyer, A., Leake, J.R., Gaston, K.J., 2011. Mapping an urban ecosystem service: quantifying above-ground carbon storage at a citywide scale. Journal of Applied Ecology 48, 1125-1134.

deVries, R.E., 1987. A Preliminary Investigation of the Growth and Longevity of Trees in Central Park. Rutgers University, M.S. thesis, New Brunswick, NJ.

Escobedo, F., Seitz, J.A., Zipperer, W., 2009. Carbon Sequestration and Storage by Gainesville's Urban Forest. University of Florida Extension publication FOR210 (last accessed Dec. 2012). http://edis.ifas.ufl.edu/fr272.

Fleming, L.E., 1988. Growth Estimation of Street Trees in Central New Jersey. Rutgers University, New Brunswick, NJ. M.S. thesis

Frelich, L.E., 1992. Predicting Dimensional Relationships for Twin Cities Shade Trees. University of Minnesota, Department of Forest Resources, St. Paul, MN, p. 33.

Gill, S.E., Handley, J.F., Ennos, A.R., Pauleit, S., 2007. Adapting cities for climate change: the role of the green infrastructure. Built Environment 33 (1), 115-133.

Heath, L.S., Smith, J.E., Skog, K.E., Nowak, D.J., Woodall, C.W., 2011. Managed forest carbon estimates for the U.S. Greenhouse Gas Inventory, 1990-2008. Journal of Forestry April/May, 167-173

Heisler, G.M., 1986. Energy savings with trees. Journal of Arboriculture 12 (5), $113-125$.

Hutyra, L.R., Yoon, B., Alberti, M., 2011. Terrestrial carbon stocks across a gradient of urbanization: a study of the Seattle, WA region. Global Change Biology 17, 783-797.

Interagency Working Group on Social Cost of Carbon, United States Government 2010. Technical Support Document: Social Cost of Carbon for Regulatory Impact Analysis Under Executive Order 12866. http://www.epa.gov/oms/climate/ regulations/scc-tsd.pdf (last accessed June 2012).

Intergovernmental Panel on Climate Change (IPCC), 2006. 2006 IPCC guidelines for national greenhouse gas inventories. In: Eggleston, S., Buendia, L., Miwa, K., Ngara, T., Tanabe, K. (Eds.), 2006. Agriculture, Forestry and Other Land Use (AFOLU), vol. 4 (last accessed January, 2010). www.ipcc-nggip.iges.or.jp/public/ 2006gl/vol4.html.

Jo, H., 2002. Impacts of urban greenspace on offsetting carbon emissions for middle Korea. Journal of Environmental Management 64, 115-126. 
Lal, R., Augustine, B., 2012. Carbon Sequestration in Urban Ecosystems. Springer, New York, p. 385.

Lewandrowski, J., Peters, M., Jones, C., House, R., Sperow, M., Eve, M., Paustian, K. 2004. Economics of Sequestering Carbon in the U.S. Agricultural Sector. Technical Bulletin TB-1909. USDA Economic Research Service, Washington, DC, p. 61

Nowak, D.J., 1991. Urban Forest Development and Structure: Analysis of Oakland, California. PhD dissertation. University of California, Berkeley, p. 232.

Nowak, D.J., 1993. Atmospheric carbon reduction by urban trees. Journal of Environmental Management 37 (3), 207-217.

Nowak, D.J., 1994. Atmospheric carbon dioxide reduction by Chicago's urban forest. In: McPherson, E.G., Nowak, D.J., Rowntree, R.A. (Eds.), Chicago's Urban Forest Ecosystem: Results of the Chicago Urban Forest Climate Project. USDA Forest Service General Technical Report NE-186, Radnor, PA, pp. 83-94.

Nowak, D.J., 2010. Urban biodiversity and climate change. In: Muller, N., Werner, P., Kelcey, J.G. (Eds.), Urban Biodiversity and Design. Wiley-Blackwell Publishing, Hoboken, NJ, pp. 101-117.

Nowak, D.J., Buckelew-Cumming, A., Twardus, D., Hoehn, R., Mielke, M., 2007a. National Forest Health Monitoring Program, Monitoring Urban Forests in Indiana: Pilot Study 2002, Part 2: Statewide Estimates Using the UFORE Model. Northeastern Area Report. NA-FR-01-07, p. 13.

Nowak, D.J., Crane, D.E., 2002. Carbon storage and sequestration by urban trees in the USA. Environmental Pollution 116 (3), 381-389.

Nowak, D.J., Cumming, A.B., Twardus, D., Hoehn, R.E., Brandeis, T.J., Oswalt, C.M., 2012a. Urban Forests of Tennessee, 2009. General Technical Report. SRS-149. U.S. Department of Agriculture, Forest Service, Ashville, NC, p. 52.

Nowak, D.J., Greenfield, E.J., 2012a. Tree and impervious cover change in U.S. cities. Urban Forestry and Urban Greening 11, 21-30.

Nowak, D.J., Greenfield, E.J., 2012b. Tree and impervious cover in the United States. Landscape and Urban Planning 107, 21-30.

Nowak, D.J., Hoehn, R., Crane, D.E., Bodine, A., 2012b. Assessing Urban Forest Effects and Values in the Great Plains States: Kansas, Nebraska, North Dakota, South Dakota. USDA Forest Service, Northern Resource Bulletin NRS-71, Newtown Square, PA, p. 75.

Nowak, D.J., Hoehn, R., Crane, D.E., Cumming, J., Mohen, S., Buckelew-Cumming, A. 2012c. Assessing Urban Forest Effects and Values: Morgantown's Urban Forest. USDA Forest Service, Northern Resource Bulletin NRS-70, Newtown Square, PA, p. 24.

Nowak, D.J., Hoehn, R.E., Crane, D.E., Stevens, J.C., Cotrone, V., 2010a. Assessing Urban Forest Effects and Values: Scranton's Urban Forest. USDA Forest Service, Northern Resource Bulletin NRS-43, Newtown Square, PA, p. 23.

Nowak, D.J., Hoehn, R.E., Crane, D.E., Stevens, J.C., LeBlanc, C., 2010b. Assessing Urban Forest Effects and Values: Chicago's Urban Forest. USDA Forest Service, Northern Resource Bulletin NRS-37, Newtown Square, PA, p. 27.

Nowak, D.J., Hoehn, R.E., Crane, D.E., Stevens, J.C., Walton, J.T., 2006a. Assessing Urban Forest Effects and Values: Minneapolis' Urban Forest. USDA Forest Service, Northeastern Resource Bulletin, NE-166, p. 20.

Nowak, D.J., Hoehn, R.E., Crane, D.E., Stevens, J.C., Walton, J.T., 2006b. Assessing Urban Forest Effects and Values: Washington D.C.'s Urban Forest. USDA Forest Service, Northern Resource Bulletin NRS-1, Newtown Square, PA, p. 24.

Nowak, D.J., Hoehn, R.E., Crane, D.E., Stevens, J.C., Walton, J.T., 2006c. Assessing Urban Forest Effects and Values: Casper, WY's Urban Forest. USDA Forest Service, Northern Resource Bulletin NRS-4, Newtown Square, PA, p. 20.

Nowak, D.J., Hoehn, R.E., Crane, D.E., Stevens, J.C., Walton, J.T., 2007b. Assessing Urban Forest Effects and Values: Philadelphia's Urban Forest. USDA Forest Service, Northern Resource Bulletin NRS-7, Newtown Square, PA, p. 24.

Nowak, D.J., Hoehn, R.E., Crane, D.E., Stevens, J.C., Walton, J.T., 2007c. Assessing Urban Forest Effects and Values: San Francisco's Urban Forest. USDA Forest Service, Northern Resource Bulletin NRS-8, Newtown Square, PA, p. 24.
Nowak, D.J., Hoehn, R.E., Crane, D.E., Stevens, J.C., Walton, J.T., 2007d. Assessing Urban Forest Effects and Values: New York City's Urban Forest. USDA Forest Service, Northern Resource Bulletin NRS-9, Newtown Square, PA, p. 24.

Nowak, D.J., Hoehn, R.E., Crane, D.E., Stevens, J.C., Walton, J.T., Bond, J., 2008. A ground-based method of assessing urban forest structure and ecosystem services. Arboriculture and Urban Forestry 34 (6), 347-358.

Nowak, D.J., Hoehn, R., Crane, D.E., Weller, L., Davila, A., 2011. Assessing Urban Forest Effects and Values: Los Angeles's Urban Forest. USDA Forest Service, Northern Resource Bulletin NRS-47, Newtown Square, PA, p. 30.

Nowak, D.J., Noble, M.H., Sisinni, S.M., Dwyer, J.F., 2001. Assessing the U.S. urban forest resource. Journal of Forestry 99 (3), 37-42.

Nowak, D.J., Rowntree, R.A., McPherson, E.G., Sisinni, S.M., Kerkmann, E., Stevens, J.C., 1996. Measuring and analyzing urban tree cover. Landscape and Urban Planning 36, 49-57.

Nowak, D.J., Stevens, J.C., Sisinni, S.M., Luley, C.J., 2002. Effects of urban tree management and species selection on atmospheric carbon dioxide. Journal of Arboriculture 28 (3), 113-122.

Nowak, D.J., Walton, J.T., 2005. Projected urban growth and its estimated impact on the U.S. Forest resource (2000-2050). Journal of Forestry 103 (8) 383-389.

Nowak, D.J., Walton, J.T., Dwyer, J.F., Kaya, L.G., Myeong, S., 2005. The increasing influence of urban environments on U.S. forest management. Journal of Forestry 103 (8), 377-382.

Pataki, D., Alig, R., Fung, A., Golubiewski, N., Kennedy, C., McPherson, G., Nowak, D., Pouyat, R., Lankao, P., 2006. Urban ecosystems and the North American carbon cycle. Global Change Biology 12,1-11.

Pouyat, R.V., Yesilonis, I.D., Nowak, D.J., 2006. Carbon storage by urban soils in the United States. Journal of Environmental Quality 35, 1566-1575.

Raciti, S.M., Hutyra, L.R., Rao, P., Finzi, A.C., 2012. Inconsistent definitions of 'urban' result in different conclusions about the size of urban carbon and nitrogen stocks. Ecological Applications 22 (3), 1015-1035.

Smith, W.B., Miles, P.D., Perry, C.H., Pugh, S.A., 2009. Forest Resources of the United States, 2007. U.S. Forest Service WO-GTR-78, Washington, DC, p. 336.

Smith, W.B., Shifley, S.R., 1984. Diameter Growth, Survival, and Volume Estimates for Trees in Indiana and Illinois. Res. Pap. NC-257. U.S. Department of Agriculture, Forest Service, North Central Forest Experiment Station, St. Paul, MN, p. 10.

Strohbach, M., Haase, D., 2012. The above-ground carbon stock of a central European city: patterns of carbon storage in trees in Leipzig, Germany. Landscape and Urban Planning 104, 95-104.

U.S. Department of Agriculture Forest Service, 2010. Forest Inventory and Analysis National Core Field Guide: Field Data Collection Procedures for Phase 2 Plots. Version 5.0, vol. 1. U.S. Department of Agriculture Forest Service, Forest Inventory and Analysis Program, Arlington, VA, p. 361 (last accessed June 2012). www.fia.fs.fed.us/library/field-guides-methods-proc/.

U.S. Census Bureau, 2007. U.S Census Data (last accessed January 2007). www. census.gov.

U.S. Environmental Protection Agency, 2010. Inventory of U.S. Greenhouse Gas Emissions and Sinks: 1990-2008. EPA 430-R-10-006. U.S. EPA, Office of Atmospheric Programs, Washington, DC. Available online at: www.epa.gov/ climatechange/emissions/usinventoryreport.html (last accessed July 2010).

Wilby, R.L., Perry, G.L.W., 2006. Climate change, biodiversity and the urban environment: a critical review based on London UK. Progress in Physical Geography 30 (1), 73-98.

Zhao, M., Kong, Z.H., Escobedo, F.J., Gao, J., 2010. Impacts of urban forests on offsetting carbon emissions from industrial energy use in Hangzhou, China. Journal of Environmental Management 91 (4), 807-813. 